\title{
Without Consent: Principles of Justified Acquisition and Duty-Imposing Powers
}

Theories of Natural Property Rights, including various classical liberal, libertarian, and left-libertarian paradigms, put forward 'Principles of Justified Acquisition.' Such principles grant humans Appropriative Powers. That is, they allow individuals to have the power to, through their activities, acquire property-rights over previously unowned objects. An important set of arguments arrayed against Appropriative Powers focuses on one ostensibly acrimonious feature - such powers necessarily involve the unilateral imposition of new duties upon the entire world's people. In appropriating a patch of land for myself, I impose new duties on every other moral entity in the world; viz. duties not to enter or utilize the appropriated land. Moreover, these duties are imposed unilaterally without the consent of these others. Appropriative Powers are in this way a member of a larger species of moral relations: they are Duty Imposing Powers. Such powers may be contrasted with other (typically more approved) moral relations, such as general rights vesting from birth, or duties which are self-imposed by consent or contract.

The cogency of Duty Imposing Powers - as a broad class of rights - has come under sustained fire in the philosophical literature. H. L. A. Hart once observed that, "to some philosophers the notion that moral phenomena - rights and duties and obligations can be brought into existence by the voluntary action of individuals has appeared utterly mysterious."1 Hart's observation was, remarkably, concerned mainly with the comparatively innocuous class of rights which can be waived or alienated, but it holds doubly true for powers which do not merely dissolve or transfer duties, but actively impose new ones. Once exposed as such, this feature draws almost inevitable philosophic disapprobation. Jeremy Waldron's critique of this feature of Appropriative Powers was lynchpin to his larger argument in The Right to Private Property, and on such a basis he averred that an Appropriative Power was, "so unlike any other ethical idea that it cannot simply be regarded as an intuitive or self-evident truth... on the face of it, it seems unfamiliar and repugnant..."2 Lief Wenar recommended, appealing to exactly such concerns over the unilateral imposition of duties, banishing Appropriative Powers to a "moral bestiary." ${ }^{3}$ Alan Gibbard articulated his preferred State of Nature by simply rejecting any and all Duty Imposing Powers (including Appropriative Powers, of course). ${ }^{4}$ Nor is this assault exclusively based on the putative weirdness or unfamiliarity of Duty Imposing Powers. Further arguments contend that no good reasons can be given which motivate acceptance of any members of this quixotic category. ${ }^{5}$ Perhaps the most telling evidence of the seeming unreasonableness of Duty Imposing Powers however, is to be found in the tentativeness of many of their advocates. Those commentators who have been willing to entertain the possibility of Appropriative Powers (and hence also

\footnotetext{
${ }^{1}$ H. L. A. Hart, 'Are There Any Natural Rights?', in Jeremy Waldron (ed), Theories of Rights, (Oxford: Oxford UP, 1984), pp. 77-90, at p. 84.

${ }^{2}$ Jeremy Waldron, The Right to Private Property (Oxford: Clarendon, 1988), p. 265.

${ }^{3}$ Leif Wenar, 'Original Acquisition of Private Property', Mind 107, no. 428 (1998), pp. 799-819, at p. 807.

${ }^{4}$ Allan Gibbard, 'Natural Property Rights', in Hillel Steiner and Peter Vallentyne (eds), Left-

Libertarianism and Its Critics (Hampshire: Palgrave, 2000), pp. 23-30, at p. 25.

${ }^{5}$ Waldron, Ch. 7 and pp. 390-392.
} 
Duty Imposing Powers), have typically accepted exacting delimitations upon these powers - for instance, that Appropriative Powers are only tenable if they do not upset competitive parity. ${ }^{6}$

All these objections to Duty Imposing Powers - I argue - are deeply misplaced. That said, the general methodology invoked in these lines of critique is worth serious exploration. Appropriative Powers are indeed Duty Imposing Powers, and occasionally we can learn something important about the motivations for a particular type of right, the problems it typically invites, and the restrictions which might ameliorate these problems, by investigating its conspecifics. As we will see in what follows, there are many wellrespected and intuitively plausible Duty Imposing Powers which can help us frame our thinking about Appropriative Powers.

My ultimate aim is therefore to open the field to the viability of Appropriative Powers by confuting all qualms arising from their status as Duty Imposing Powers. Despite this narrow focus, the scope of the general question under examination is very broad, and for this reason the following analysis may provide significant resources to those who have no interest in property rights per se. The basic question of whether one agent can unilaterally impose new duties on another is pivotal in, for instance, Robert Nozick versus Hart's principle of restrictive mutual obligations, ${ }^{7}$ Judith Jarvis Thompson versus violinists, ${ }^{8}$ the very possibility of the formation of the political state sans ubiquitous consent, ${ }^{9}$ and so on.

Before beginning, some further specificity of Duty Imposing Powers, and clarification of terminology, is in order. ${ }^{10}$ If you have a 'liberty' to phi that simply means you do not have a duty to refrain from phi-ing. Your 'claim-right' to phi typically involves a negative duty in some or all others to refrain from intruding in your phi-ing or your opportunities to phi, and on some accounts may even require a positive duty on others that they actually help you phi. Many claim-rights are also general rights; they vest automatically from birth. ${ }^{11}$ A 'power' allows you to place someone in a new moral relation - most notably a power allows you to waive or impose duties on some others or yourself (for instance you might waive others' non-trespassing duties by inviting them to your house for dinner, or impose new duties on yourself by making a promise). Many powers allow you to change moral relationships only in concert with consenting others these may be called 'participant powers'. ${ }^{12}$ For expository ease I will generically refer to

\footnotetext{
${ }^{6}$ See $\S 3.2$ below.

${ }^{7}$ Robert Nozick, Anarchy, State, and Utopia (Oxford: Basil Blackwell, 1974), pp. 90-95, Hart, 'Are There Any Natural Rights?’, at p. 85.

8 Judith Jarvis Thomson, ‘A Defense of Abortion', Philosophy and Public Affairs I, no. 1 (1971), pp. 47-66

${ }^{9}$ E.g. D. A. Lloyd Thomas, Locke on Government. (London: Routledge, 1995), Ch. 2.

${ }^{10}$ The key terms here derive from Hohfeld's classic fragmentation of the right: W. N. Hohfeld, 'Fundamental Legal Conceptions as Applied in Judicial Reasoning', Yale Law Journal 26 (1917), pp. 710769. q.v. Leif Wenar, 'The Nature of Rights', Philosophy and Public Affairs 33, no. 3 (2005), pp. $223-252$.

${ }^{11}$ The term 'general rights' suffices for referring to those rights which are not created by special actions or interactions, provided we bear in mind that, strictly speaking, general rights are defined as those rights which are possessed by all and hold against all others.

${ }^{12}$ E.g. the power to marry. See Lawrence C. Becker, Property Rights: Philosophic Foundations (London: Routledge, 1977), at p. 14.
} 
any personal advantages secured by moral law as 'rights' - thus including inter alia both claim-rights and powers. ${ }^{13}$

All powers by definition alter the ethico-legal relations of the agent with others. However, the specific class of powers which interests us here is further constrained: someone without your consent deliberately does $\mathrm{X}$ with an expectation that their successful $\mathrm{X}$-ing will morally require you to $\mathrm{Y}$; moreover, you Y-ing is (perhaps given the results of their $X$-ing) advantageous to them in some way. ${ }^{14}$

One important difficulty with investigating this issue is a problem of vagueness. Consider the right to privacy. Reasonably, we might think that such a right is ongoing in the sense that you always have such a right - but that it requires a specific assertion, and perhaps specific activities, in order to be activated. For example, in order to appropriately activate your right to privacy you might need to ask others to leave you alone as you retire to a secluded place. Similar requests and actions are involved in activations of one's rights to freedom of speech and association. ${ }^{15}$ It seems a little strong to say to say any such request imposes new duties on others. Rather, it is more intuitive to say that the request merely activates duties in these others - and hence I will refer to these types of rights as Duty Activating Powers. Notwithstanding such a categorisation, it should be clear that we are dealing with a continuum where Duty Imposing Powers arise out of Duty Activating Powers as mountains may arise out of molehills. Many of the Duty Imposing Powers I put forward in the course of this argument could conceivably be reconstrued as Duty Activating Powers. I have little concern with such a re-categorisation - the same moral issues are in place regardless of our semantic stipulations. Indeed, as we will see, Duty Activating Powers are morally useful and morally problematic in very much the same ways as Duty Imposing Powers.

\section{Section I: Are Duty Imposing Powers Weird or Unfamiliar?}

Several commentators have already noted that Waldron may have been a little hasty in attributing unfamiliarity to the duty-imposing feature of Appropriative Powers, but the counter-examples offered have not been definitive. Gerald Gaus and Loren Lomasky discuss desert-based injunctions in institutional settings ${ }^{16}$ and A. John Simmons advances possible rights to make legal wills, patent inventions, monopolise public parks, disrupt country walks and buy rare stamps - thus removing them from sale. ${ }^{17}$ While some of these examples might be instances of Duty Imposing Powers, unfortunately, apart possibly from the public park case (which may fall under a right to possession/occupancy; see below) all these examples involve structural features which would allow Waldron's charge of idiosyncrasy to stand. Institutionally recognised desert may potentially be

\footnotetext{
${ }^{13}$ Officially, this typology is a 'capacious' theory of rights; see Rowan Cruft, 'Why Aren’t Duties Rights?', The Philosophical Quarterly 56, no. 223 (2006), pp. 175-192, at pp. 177-181.

${ }^{14}$ I have superadded this condition regarding expectations and advantages (alternate construals might refer to interests or reasons). Several commentators argue that some such provision is itself a necessary condition of normative powers. E.g. Joseph Raz and Neil MacCormick, 'Voluntary Obligations and Normative Powers', Proceedings of the Aristotelian Society, Supplementary Volumes 46 (1972), 59-102, at pp. 80-81.

${ }^{15}$ See $\$ 3.2$ below.

${ }^{16}$ Gerald F. Gaus and Loren E. Lomasky, ‘Are Property Rights Problematic?’, Monist (1990), pp. 483-503, at p. 492.

17 A. John Simmons, 'Original-Acquisition Justifications of Private Property', Social Philosophy and Policy 11, no. 2 (1994), pp. 63-84, at p. 83.
} 
explained on the basis of actual or implied consent. Legal wills, country walks and philately don't even appear to impose new moral duties at all - or, at least, not in the straightforward sense in which Appropriative Powers do. Finally, appeals to patent will hardly impress Waldron; he would no doubt respond that intellectual property acquisition is on no safer ground than its more tangible cousin.

To assess this charge of idiosyncrasy, let's recount a quick laundry list of what a peremptory dismissal of Duty Imposing Powers would preclude. I do not suppose that all readers will find all of the following examples an acceptable part of their embraced moral repertoire. However, I think many will find most of the following examples quite plausible, and the last several - procreation, possession and occupancy - are perennial inclusions in liberal regimes and most States of Nature envisaged by natural rights theorists. Those with a legal background will also recognise many of the following as not merely actions that can impose moral duties, but legal duties as well. Nor is this list supposed to be exhaustive. Perhaps the most controversial omission will be any mention of gratitude. Indeed, in D. A. Lloyd Thomas's brief discussion of involuntarily imposed duties, the role of gratitude (as owed by children to loving parents) is taken as the exclusive exemplar of a Duty Imposing Power. ${ }^{18}$ However, outside of very specific circumstances like rescue, salvage and unjust enrichment (see below and §4), gratitude per se creates few well-accepted and clearly delineable rights. Note that while X performing a favour to $\mathrm{Y}$ can create duties for $\mathrm{Y}$, such duties seem tacitly accepted if $\mathrm{Y}$ requests the favour. Without such request, the creation of specific duties becomes much less plausible. ${ }^{19}$

Caveats aside, potential examples of Duty Imposing Powers include:

- being provided with details of a crime (historical or imminent) may impress duties upon one to report information to appropriate authorities.

- being rescued from disaster, or having one's property saved, might impose duties to compensate the rescuer for losses incurred through her action.

- recording one's personal thoughts in some physical device (e.g. a journal) might create new duties of privacy on others, while being told a secret often mandates new duties of confidence.

- creating an object of aesthetic, spiritual or cultural significance may mandate new duties of protection or reverence for that object.

- being vested with legal powers on the basis of one's role or occupation often demands that others, who did not have had veto rights within this authorisation process, acquire a duty to respect such powers. A mild case occurs when we must obey certain commands of a newly deputed town-official; a stronger case might involve the election of a magistrate who can change, for example, the terms of procedural justice.

- $\quad$ engaging in morally excellent activity might involve others being duty-bound to respond in some respectful way.

\footnotetext{
${ }^{18}$ Lloyd Thomas, pp. 52-3.

${ }^{19}$ A thoughtful introduction to these complexities is Jane English, 'What Do Grown Children Owe Their Parents?', in W. Ruddick and O. O'Neil (eds) Having Children: Philosophical and Legal Reflections, (New York: Oxford, 1979), pp. 351-356. In my discussion of foisting in §4 I develop resources that may help us judge in which cases an acceptance might have the same force as a request.
} 
- being mistakenly paid (or over-paid) typically imposes a duty to return at least some of the windfall - as may innocently coming into possession of stolen property.

- creating or sustaining through communal labor or abstinence a public good - in a case where another's use of that good might consume or destroy it - might create duties on that other to restrict their usage.

- if we think that the process of attaining one's maturity (becoming socially accepted as an adult) involves some deliberate, conscious actions as well as involuntary physiological changes, then simply acquiring the rights of adulthood is a Duty Imposing Power. Though we are accustomed to this change occurring at a legally stipulated age, this threshold is chosen because it is held that by this point the agent has become capable of making responsible decisions. And how this change in the person may have occurred, or may have been made socially visible, may well have involved voluntary actions.

- becoming accredited with a particular proficiency alters others duties in a similar way to maturation. When a person learns to drive, for example, others are no longer straightforwardly permitted to prevent their piloting a vehicle.

- deliberately having a child creates a new entity which has its own moral demands. Even if these new duties are largely negative, they are nevertheless imposed on everyone in the world. Furthermore, in an environment with seriously depleted natural resources, any new person's claim on such resources may be an onerous imposition on all others.

- $\quad$ and finally, that closest cousin and the clearest analogue of an Appropriative Power, the right to physical possession - and the cognate rights to occupancy of a place of shelter and to wearing clothing. ${ }^{20}$

This last Duty Imposing Power is hardly especially controversial. If Annie picks up a flower on her walk through the forest, it would be wrong, ceteris paribus, for someone to snatch it from her hands and run away with it, even if they did so without actually touching Annie. When such possessions come to include the crutch Annie needs to walk, the food she has to eat, and the cloak which wards off the cold, such duties plausibly become enforceable. Yet this right to possession has very similar structural characteristics to those found in Appropriative Powers - it allows one person to exclude another from utilising an object (for so long as it is held), to transfer their exclusionary right to another (by physically passing), and - because some uses of the possessed object are consumptive or transformative - allows others to thereafter be permanently excluded from using the original object. The right to wear clothes, and the right to occupancy, are also Duty Imposing Powers with very close structural properties to Appropriative Powers.

In what follows I assume that at least some of the above rights are sufficiently plausible that they can help us understand the positive reasons for having Duty Imposing Powers, and may provide a touchstone in articulating the types of criteria we generally expect rights to meet - criteria we can then use to assess more contentious Duty Imposing Powers such as Appropriative Powers.

\footnotetext{
${ }^{20}$ Waldron (p. 270) notes possession's structural similarity to Appropriative Powers. He then argues that the right of possession is different to the latter, and cannot be seen to give rise to it. But he seems to forget that his purpose at this stage in his argument (p. 269) was not to find a normative ground for Appropriative Powers but to find an analogue for their structural curiosities.
} 


\section{Section II: Positive Reasons for Duty Imposing Powers}

From the foregoing examples we can distil two important positive reasons for having Duty Imposing Powers. ${ }^{21}$ Firstly, they allow the moral law to decree that some important changes in the world can be morally relevant and can elicit moral response. Consider what it would be to reject all the norms we have canvassed above, and any analogous powers. It would incapacitate the moral law by rendering it incapable of responding to: changes in the status of moral agents (the attainment of maturity, positions of authority, moral excellence, or driving skill), the deliberate creation of new human beings (procreation), the creation of some object which is an intimate self-expression of its creator's personality (the journal, artwork, a shared confidence), the fact that fallible human agents can make mistakes (mistaken payments of debts), and the incorporation of particular resources into people's personal and communal projects (possession, occupancy and clothing, protection for public goods, creation of cultural artifacts).

Some changes in the world - it is true - can be dealt with by allowing mutual consent and contract to be the sole creators of new duties. But in many environments, 'mutual consent' - or veto-power as we could equally well call it - might be no more than a euphemism for exploitation, free-riding, conservatism, logrolling or filibustering. In the types of changes and creations involved in the aforementioned Duty Imposing Powers, allowing veto rights to any person who has duties imposed on them would allow persons very peripherally affected to have and exploit regency over decisions which most vitally affect just one or two people.

Duty Imposing Powers arise naturally in liberal regimes because they are an essential part of any moral purview which concerns itself with one person's interference with another person's projects. This is a political vision closely associated with J. S. Mill, Locke and most particularly Kant: the quintessentially liberal precept that "the state is concerned to prevent each man exercising his freedom in such a way as to impede the free actions of others; it employs coercion to defeat coercion and nothing more..."22 If one person commits themselves to a project, works at it, and it plays an ongoing, important, self-sustaining or self-expressive role in that person's life, then the liberal will usually consider there is at least something to be said for respecting that project, even if such respect is ultimately defeated by other moral considerations. Duty Imposing Powers are crucial in respecting such projects insofar as they can protect the consequences of such projects - the changes and creations wrought - and hence play a central role in respecting the time, energy, thought, personality and sacrifice invested in such a project.

Secondly, Duty Imposing Powers (and also Duty Activating Powers) allow us to finesse an imposed duty to no more than required - the duty is imposed if and when it is warranted, and not otherwise. One minor reason for this protocol is that it could prove excessively tedious continually waiving rights via explicit consent. Imagine if we had to waive our rights to privacy before anyone could talk to us.

More importantly however, maintaining that a right must vest continually from birth on and that the duty is always in force until stipulated otherwise may involve us all in difficult and demanding duties which are actually not useful to the persons whose

\footnotetext{
${ }^{21}$ These two reasons are adduced against Waldron’s lynchpin claim (Ch. 7 and pp. 390-392) that Duty Imposing Powers (and hence Appropriative Powers) are peculiarly difficult to justify.

${ }^{22}$ Alan Ryan, Property and Political Theory (Oxford: Blackwell, 1984), p. 73.
} 
rights are being respected. Allowing people to impose the duties - especially if the dutycreating-action is not effortless - can ensure that the duty is only imposed when it is actually going to be used, when the recipient actually has a genuine stake and ongoing interest in the protection created by the right. In other cases, structuring the right as a Duty Imposing Power can ensure that individuals imposing the duties are provided the duties in the precise circumstance which befits their purposes. For instance, Edward Feser notes that Hayekian efficiency may arise not only for market interactions but also for initial acquisitions, as people choose plots of land whose features and location are peculiarly suited to their own situation and intentions. ${ }^{23}$

These are both compelling - and in some cases inescapable - reasons for having Duty Imposing Powers. But these reasons are not always present, and even when they are, other exigencies press against them, and internal pressures circumscribe them. It is to such considerations I now turn.

\section{Section III: Criteria common to all rights}

Historically, when Appropriative Powers have been proposed, accompanying delimitations have also been advanced. When some political theorist suggests that an Appropriative Power would be acceptable if, for instance, 'it does not worsen the situation of any other person compared to cooperative ventures which could counterfactually have been undertaken, ${ }^{24}$ it is reasonable to wonder how this criterion arose and on what basis it was felt to be decisive. Is the criterion supposed to have arisen naturally and self-evidently out of the mere fact that duties are being unilaterally imposed? Or is it a criterion which all rights must meet, but which Duty Imposing Powers encounter key problems in fulfilling? In either case, we should be able to see some evidence of this type of restriction being operative in other well-accepted rights. Pursuing this thought, the analysis of this section proceeds from an examination of the applied functioning of commonly accepted rights to observe ways in which Appropriative Powers might depart from such functioning. The following section (§4) will examine the applied functioning of commonly accepted Duty Imposing Powers to discern problems (and hence appropriate delimitations) specific to that class of rights.

The simple observation guiding the following analysis is that many commonly proffered criteria for Appropriative Powers cannot be applied to well-accepted rights. Now if some right $X$ has invidious characteristics compared to some other plausible rights $\mathrm{Y}$ and $\mathrm{Z}$, then it is prima facie strange that in order to express our concerns about $\mathrm{X}$ (and to dictate the conditions under which $\mathrm{X}$ might be rendered acceptable) we need to appeal to criteria that $\mathrm{Y}$ and $\mathrm{Z}$ fail. Reasonably, we should be able to demarcate the infelicitous quality of $\mathrm{X}$ by reference to criteria or desiderata that $\mathrm{X}$ fails, but that $\mathrm{Y}$ and $\mathrm{Z}$ pass. The following analysis aims to isolate with some precision such a list of criteria/desiderata.

\footnotetext{
${ }^{23}$ Edward Feser, 'There Is No Such Thing as an Unjust Initial Acquisition', Social Philosophy and Policy 22, no. 1 (2005), pp. 56-80, at p. 64 fn. 19. q.v. F.A. Hayek, 'The Use of Knowledge in Society', The American Economic Review 35, no. 4 (1945), pp. 519-530.

${ }^{24}$ See $\S 3.2$.
} 


\section{Sect III.I: The 'Universalisability' Criterion}

All proposed rights must undeniably be universalisable. Unfortunately it is not pellucid what this criterion must involve. Allow me to sketch three intuitive senses we might give to the universalisability criterion (where 'phi-ing' is some activity):

Formal Universalisability: 'If I morally assert the freedom to phi, it is only reasonable that I respect the freedom of others in their phi-ing.'

Robust Universalisability: 'If I morally assert the freedom to phi, it is only reasonable that, as a result of my phi-ing, I do not undermine the opportunity of others to phi.'

Generous Universalisability: 'If I morally assert the freedom to phi, it is only reasonable that I make some efforts (in concert with other similarly placed others) to ensure that others are placed in a situation where they too can phi.'

Observe how this would work when applied to an ordinary claim-right, such as the freedom to engage in unimpeded bodily movement. Formal Universalisability requires that this freedom could not, on pain of inconsistency, allow me to physically impede others' bodily movements. My right to extend my fist is not annulled on this basis, but is cabined to ensure it does not extend past your nose. Robust Universalisability would further require that my exercise of this freedom cannot allow me to undermine your opportunities to freely engage in such movements. This criterion would demand that I cannot physically trap or surround you in order that you cannot move anywhere without breaching my rights to bodily sanctity and free movement. Generous Universalisability would require that I commit to helping those who cannot currently move their bodies to achieve mobility.

Which type of universalisability is found within well-accepted rights? Clearly, in the above example, Robust Universalisability accurately captures the well-accepted restrictions on the right; we cannot use our right to free bodily movement to impose duties which unduly restrict the similar movements of others.

What about a duty-activating-power such as freedom of speech in certain public forums without being shouted down or silenced? (This is to be understood here in the broad sense of being entitled to speak if one requests to do so and observes due process) Formal Universalisability would dictate that, as I expect others not to silence me as I speak, so too when they are speaking I will not silence them. Robust Universalisability would require that I do not monopolise the stage and keep talking at the expense of others who wish to have a turn. Plausibly, robust universalisability again delineates the demands of this right; others would hardly feel they should remain respectfully quiet if I were unwilling to cede the stage to anyone else.

Duty Imposing Powers appear similarly constrained. Earlier I suggested that Duty Imposing Powers such as procreation, possession and occupancy were very plausible. However, in cases where such powers allow a person to derogate others' opportunities for themselves activating such powers, any intuitive plausibility quickly dissipates. Possession or occupancy of resources which are sufficiently scarce so as to remove others' opportunities to make similar possessory actions does not seem obviously acceptable. Similarly, in an environment where resources were egregiously scarce, we might well find that procreation would be limited to allowing each couple to have only as many children as is consistent with all other desiring couples to do likewise. 
Thus many well-accepted general rights, Duty Activating Powers and Duty Imposing Powers evince a criterion of Robust Universalisability. Are there telling counter-examples to this claim? There are two putative counter-examples and each must be dealt with distinctly. The first case occurs when, on a sunny morning, many people spontaneously decide to go to the beach - something they are all at liberty to do. However, the beach quickly fills up with the people, and later arrivals cannot find the space to lay down their towels. Clearly, some people's liberty to use the beach has undermined the similar opportunity of others to do so. That much admitted, it is not clear that - if an organized response were possible - a fair allocation of time-space slots on the beach would be either inappropriate or counterintuitive. Even in cases where an institutional response is impossible, persons may morally respond to the situation spontaneously by not spreading themselves out on the beach as much as normal, and limiting their stay to ensure others can have an equal turn. In the similar case of queuing for public telephones, various informal norms do arise - for instance a socially enforced 'two minute' limit on calls. In such cases, we might consider Robust Universalisability a very important desideratum, but perhaps not always a necessary condition. If a regime of Robust Universalisability were difficult to organise or enforce in some case, then we might have to accept Formal Universalisability faute de mieux.

A second possible counter-exemplary case lies in the fact that the freedom to marry (indeed, freedom of association in general), when invoked and exploited by some persons can create circumstances where another person can no longer successfully exploit the right, there being no more people to marry, for instance. Unlike the above example however, upon analysis this situation cannot be correctly characterised as a counterexample to Robust Universalisability. Earlier I categorized the right to freedom of association as a Duty Activating Power. Central to this right is the liberty and power to request some level of personal space - similar to the activation occurring in the aforementioned privacy right - and the liberty and power to invite select others into it (and the immunity from others having powers to dissolve these rights). The songwriter Ani Difranco neatly distils the plausible activation-conditions: 'Think I'll go for a walk now. I feel a little unsteady. Don't want nobody to follow. 'Cept maybe you.' There is in addition a power of contract to change one's own moral relationships, as when one agrees to the terms of a club or trade union. These are the politico-moral resources secured by the right and necessary for its activation. And they are nowise infracted upon by anyone else's exploitation of the right, no matter how sweeping or successful. Another person's time or attention is not what is being demanded by a person asserting their right to freedom of association. Rather, such time or attention is one result of the right's successful exploitation.

Thus Robust Universalisability is a typical feature of most well-accepted rights. If not a defeating criterion, it is at least a powerful desideratum. As applied to Appropriative Powers, Robust Universalisability confronts us, as Hillel Steiner puts it,

"with the problem of formulating a ... rule which somehow assigns the same kinds of right to all individuals as were enjoyed by those licensed to make the 'first moves',"25

The obvious protocol which would support Robust Universalisability is the Lockean proviso to leave 'as much and as good' for others. ${ }^{26}$ Such a protocol ensures that my

${ }^{25}$ Hillel Steiner, 'Justice and Entitlement', Ethics 87 (1977), pp. 150-152, at p. 151. 
appropriation now is not of such scope or power as will prevent other (future) persons having similar opportunities to do what I am now doing. Contrariwise, the strong libertarian Appropriative Power of 'finder's keepers ${ }^{27}$ breaches robust universalisability.

The resulting regime potentially allows the appropriation of land, and the rights to exclusivity, some alienability, and the value added through one's labor - but permanent tenure will not be justified. Very broadly, the limited-property regimes articulated by several classical liberals, ${ }^{28}$ later $19^{\text {th }}$ Century theorists such as Henry George, and modern day left-libertarians such as Steiner ${ }^{29}$ would be justified by this account.

\section{Section III.II: The Non-Worsening Criterion}

Some theorists have argued however, that leaving 'enough and as good' is not sufficient to compel acceptance of an Appropriative Power, and that Appropriative Powers are unacceptable if they worsen the condition of others. Is this a criterion that we can find reference to within other rights - especially within Duty Imposing Powers? I argue that this is an important concern, but that theorists have commonly represented its demands more strongly than the current analysis would support.

Before beginning, let me adumbrate some basic reasons for imposing a nonworsening criterion. In a given liberal paradigm, any particular right may be but one facet of a larger, taproot right, or only one among a plurality of morally protected interests. In such cases, the particular right must be curtailed to ensure that its functioning does not vitiate for others the protections sustained by the core right, or the other key rights. ${ }^{30}$ Alternatively, it might be held that liberalism itself is fundamentally about articulating how we can interact with other people in such a way that these others benefit from (or at least are not worsened by) our presence. ${ }^{31}$

Having established at least some independent motivation for concerns with 'nonworsening', let us now consider five separate interpretations of such a condition. It might be suggested that your act of appropriation is unacceptable (perhaps even harmful) if it worsens my position...

1. as compared to some patterned distributive justice outcome, particularly an egalitarian outcome. $^{32}$

2. as compared to cooperative ventures you and I could have otherwise engaged in. $^{33}$

\footnotetext{
${ }^{26}$ John Locke, Two Treatises of Government, (Hafner: New York, 1947), ii, § 27, 33, 36. There is a voluminous exegetical literature on this point. Broadly, the proffered interpretation is defended in A. John Simmons, The Lockean Theory of Rights (Princeton: Princeton University, 1992). Ch 5.

${ }^{27}$ Feser, pp. 65/66. Jan Narveson, 'Property Rights: Original Acquisition and Lockean Provisos', Public Affairs Quarterly 13, no. 3 (1999), pp. 205-227, at pp. 214-216.

${ }^{28}$ A pertinent anthology is Peter Vallentyne and Hillel Steiner (eds), The Origins of Left-Libertarianism (New York: St. Martin's Press, 2000).

${ }^{29}$ Hillel Steiner, An Essay on Rights (Oxford: Blackwell, 1994), pp. 268-272.

${ }^{30}$ Joseph Raz, The Morality of Freedom (Oxford: Clarendon Press, 1986), pp. 168-70.

${ }^{31}$ e.g. Jan Narveson, 'Contracting for Liberty', in Tibor R. Machan and Douglas Rasmussen (eds) Liberty for the Twenty-First Century (Lanham, Md.: Rowman \& Littlefield, 1995), pp. 19-41, at pp. 20-24.

${ }^{32}$ e.g. Jean-Jacques Rousseau, 'Discourse on the Origins of Inequality', in Collected Writings of Rousseau; V. 3. (Hanover, NH: University Press of New England, 1992), p. 43. Even Locke seems to suggest that some levels of material inequality require special justification (tacit consent to money). Locke, ii, § 45-51.

${ }^{33}$ G. A. Cohen, Self-Ownership, Freedom and Equality (Cambridge: Cambridge University, 1995), pp. 82/83, 86/87.
} 
3. as compared to the competitive standing (and subsequent economic opportunities predicated on such standing) I held prior to the acquisition. ${ }^{34}$

4. as compared to my material condition prior to the acquisition, where such position includes capacities and opportunities (in particular my capacity to make a living ${ }^{35}$ ) but excludes reference to cooperative ventures and competitive standing (i.e. to the concerns of (2) and (3) above).

5. by morally proscribing me from undertaking actions which are urgently needed for the sustenance of my life or that of my dependents. ${ }^{36}$

Of course, many philosophical theories have tried to argue from plausible fundaments to the conclusion that one or other of these criteria are justified. My more 'surface-level' interest here is in determining whether the above criteria pick out a difference between Appropriative Powers and other rights (and hence is a seeming natural concern to voice), or whether most other rights would equally fail such a 'nonworsening' demand.

Marx deftly puts the riposte to the first criterion: observing the paradigmatic Appropriative Power - the right to the fruits of one's labour - Marx observed that the power was:

“a right of inequality, in its content, like every right. Right, by its very nature, can consist only in the application of an equal standard; but unequal individuals (and they would not be different individuals if they were not unequal) are measurable only by an equal standard insofar as they are brought under an equal point of view, are taken from one definite side only..., 37

Try as we might to hold certain duties or rights fixed, diverse individuals will respond to, and flourish within, the interstices provided by those rules in different ways and with different degrees of success. For some persons, a given right will allow vistas of opportunity which another person simply does not have the physical or psychological wherewithal to exploit. Indeed, such 'opportunities' may not even be recognisable as opportunities, given that person's particular life-plan. For some persons, a given duty will be a profound and vexatious impediment to their pursuit of happiness, while another will barely notice its demands. Ultimately, almost all rights are not constrained by criteria demanding their equitable results - for every given right there are inequalities which it can be seen to sustain and exacerbate, as compared to a world without that right.

The second criterion is equally absent. Well accepted rights would almost all summarily fail a criterion demanding that such a right not worsen another's position compared to available cooperative ventures. To accept such a criterion would simply dissolve the individualist character of rights. My rights to freedom of speech, religion and association, for instance, may surely worsen the state of others, if such 'worsening' is compared to more cooperative activities these others would rather I performed with them.

\footnotetext{
${ }^{34}$ Becker, pp. 42/43. Alan Ryan, Property. (Milton Keynes: Open University Press, 1987), 63/64.

35 This proviso may be attributed to Locke; Ryan, Property and Political Theory, p. 47. Simmons, The Lockean Theory of Rights, p. 293. and to Rousseau, Ryan, Property, pp. 48/49.

${ }^{36}$ e.g. Locke, ii, § 42, Hugo Grotius, De Jure Belli Ac Pacis Libri Tres, trans. F. W. Kelsey, Classics of International Law. (Washington: Carnegie Institution of Washington, 1913), II, Ch 2, Sect vi.

${ }^{37}$ Karl Marx. "Critique of the Gotha Programme." In Marx/Engels Selected Works. (Progress Publishers, 1970), http://www.marxists.org/archive/marx/works/1875/gotha/index.htm (accessed Oct 2006).
} 
The third criterion also fails. Preservation of the competitive status quo is not respected by myriad rights. The zones of liberty set up by basic claim-rights ensconce all sorts of actions which allow you to benefit yourself in ways that greatly affect your competitive standing compared to others - eating well, exercising, thinking, practicing, learning from mistakes, and so on. ${ }^{38}$ Duty Activating Powers similarly breach this criterion - being able to choose who you will associate and undertake projects with allows agents massive possibilities for shared gains by building relationships of trust. As for Duty Imposing Powers, the capacity to possess a stick and carve it into a spear or a crutch radically alters one's competitive prospects, as does occupying a lean-to which protects from the wind and rain, as does having children.

The fourth criterion - regarding worsening another's (non-competitive) material standing and in particular their capacity to make a living - is not so easily dispatched. General rights typically do not protect actions which wantonly destroy or consume natural resources required by others for their projects. Concern for such worsening is similarly found in most Duty Imposing Powers. Consider possession and occupancy. Such powers do not allow direct interference with others' projects and they protect the objects that others possess and occupy as they engage in their projects. Additionally, such powers do not unproblematically allow taking possession of a unique natural resource exclusively occupying a crucial trade route or watering hole can hardly be asserted to be a 'well-accepted' usage of occupancy. It is not enough that others are left equally desirable places to themselves occupy; rather, we must also avoid interfering with their other projects of (say) travel and trade. Thus, interdicting directly in another's ongoing projects, or destroying the capacity for others to engage in such activities, is a type of worsening that is not typically found in well-accepted rights.

The fifth criterion similarly reveals a point of difference. Almost no well-accepted rights morally preclude others from taking such action as is urgently required to sustain their lives or that of their dependents. Of course, bodily rights do prevent cannibalism, even for the starving, but such an act fails robust universalisability. Setting aside such non-universalisable acts, we might be drawn to accept a negative right of necessity, in the sense that one cannot interfere with a destitute other's most basic quest for sustenance.

The conclusions of this overall section are that we accept a criterion of Robust Universalisability (and hence a condition similar to the Lockean proviso) and that we accept the fourth and fifth criteria of non-worsening (and hence accept a right of necessity, and ensure that appropriation does not impinge on others' key interests, including, arguably, opportunities for travel, trade, free-speech, free-association, and selfeducation). An Appropriative Power which does not fulfil such criteria could be faulted as failing to fulfil very basic desiderata which appear in numerous other rights.

\footnotetext{
${ }^{38}$ Rousseau, at least, is consistent on this point. His attack on property is of a piece within his equivalent condemnation of civilisation, society and the moral law. Rousseau (pp. 43-51, 62) was acutely aware of the inequitable consequences elicited by the most basic activities, liberties and social arrangements.
} 


\section{Section IV: Idiosyncratic problems with Duty Imposing Powers}

In this last section I consider whether Appropriative Powers should be forced to answer to some extra criteria on the basis of features of Duty Imposing Powers which are not found in general rights and consensual duties - criteria which are often elided in the standard philosophical analyses. Imposing new duties on a non-consenting person does have specific consequences which are clearly morally worrisome and arise directly from this feature.

A significant resource illuminating the following discussion is case law and legal commentary. ${ }^{39}$ There are many ways in which the law allows obligations to arise without consent or wrong. Some of these Duty Imposing Powers were mentioned in passing in $\S 1$ - the law of negotiorum gestio obliges rescuees to recompense their rescuer for losses incurred in the rescue, the law of unjust enrichment requires beneficiaries of mistaken payments to refund their windfalls (and analogical cases such as where one person has without wrong - intercepted monies that would otherwise have rightfully come to another ${ }^{40}$ ) and Equity imposes obligations against breach of confidence. ${ }^{41}$ There are also other legally recognised Duty Imposing Powers which were not mentioned earlier. For example: intellectual property law prohibits certain types of copying; the law of salvage gives salvors rights to rewards commensurate with the value of the cargo or vessel salvaged, and laws of accession (if X's seeds are planted in Y's ground) and specification (if X makes something out of Y's materials) unilaterally alter property rights. Equity also treads a fine line between full-blown Duty Imposing Powers and duties-imposed-bycontract by imposing duties on the basis of an agent's status. As Sarah Worthington notes:

"although it is commonly said that no one can be made a fiduciary against

his will, the only real escape is to avoid the relationship itself... Every

company director is automatically a fiduciary, for example, with all the

constraints on personal autonomy associated with that status.”42

Equity's brand of impositions, though they are not strictly Duty Imposing Powers, amplify that the law is accustomed to imposing duties which do not either vest from birth or arise from consent. These myriad legal examples were passed over earlier not because they are implausible, but simply because they appear comparatively contentious - anyone who questions the propriety of Appropriative Powers will hardly have their concerns assuaged by analogy to copyright. The point of this final section is not to peruse what positively motivated these powers, but rather to observe the types of constraints - and the reasons suggested for those constraints - recognised by the law, with a view to discerning worrisome features that Duty Imposing Powers present which consensual and general rights do not. In all, there are seven different considerations that give us pause in the acceptance of - and may rightly curtail - Duty Imposing Powers.

\footnotetext{
39 The following analysis borrows heavily from Wendy Gordon's comprehensive exploration of the tort of misappropriation. Gordon canvases concerns with officiousness, autonomy, worsening, comparativecontribution and macro-level considerations. Wendy Gordon, 'On Owning Information: Intellectual Property and the Restitutionary Impulse’, Virginia Law Review 78, no. 149 (1992), 149-281.

${ }^{40}$ Peter Birks, Unjust Enrichment (Oxford, England: Oxford University Press, 2003), pp. 66-72.

${ }^{41}$ Sarah Worthington, Equity (Oxford: Oxford University Press, 2003), pp. 136-142.

${ }^{42}$ Worthington, pp. 123, 129.
} 
First, Duty Imposing Powers can be officious; that is, they can potentially allow the duty-imposer to personally intrude in the life of another person. Ordinary citizens are typically in control of the precise individuals with whom they will engage in special moral relationships - in particular with whom they are willing to become indebted. Duty Imposing Powers must be operationalized in such a way as to prohibit one person forcing themselves into a personal moral relationship with another.

Second, the foregoing analysis emphasized that Appropriative Powers were not allowed to worsen other's situations by worsening their material position (except in competitive ways). But there are novel ways in which some Duty Imposing Powers can do exactly this. The paradigmatically invidious Duty Imposing Power is that of the foisting of benefits. Foisting occurs when I create a benefit for you, impose it upon you without your consent and then demand market-price compensation. The glaring problem is that the benefit imposed may not be worth its market value to you; there are innumerable goods for which any given person would not pay current market-price. The imposition of new duties should not worsen your prior position, in line with our fourth 'non-worsening' criteria accepted above, and this type of foisting allows exactly this.

The third worry is that the imposition might undermine a person's autonomy qua chooser. Even in cases where the benefit actually is personally worthwhile at the cost which is subsequently extracted, such foisting may paternalistically disrespect the beneficiary's autonomy. It is not enough to show that a good thing happened to someone - we might feel that sometimes the moral crux is that the person was able to make this choice for themselves. After all, sometimes our choices are not made simply on the basis of our preferences, but are a way we have of freely realising or constituting such preferences. Furthermore, one way we can control our decisions is to control the opportunities to which we are exposed. If some clever chocolate-seller put chocolate in my fridge 'on commission' - leaving me free to eat (and hence buy) it or not - the fact that I would inevitably eat it all does not respect the meta-choice I normally make to keep myself at arms-length from such weighty temptations. Modern hotel bar-fridges exploit exactly this human weakness. Unilateral impositions of duties even when mutually beneficial to all parties can efface the importance of these types of autonomy.

Fourth, even when the benefit foisted truly is a great benefit, and even modulo issues of autonomy, it is still not straightforward that the beneficiary should owe anyone anything. Suppose I am legally able to access some resource of yours which I go on to use to incredible and unforeseen effect. Your resource benefited my life immensely - but do I owe you on that basis? Did your making that resource available to me (or your being unable to legally prevent me from accessing it) unilaterally impose duties on me to make restitution to you? Our answer to this question may hinge on our assessments of the contribution of each party. If I did little to your product but copy and expose it to a new market (if that) then perhaps I owe you significant restitution. ${ }^{43}$ Alternatively if your product was merely one piece in a larger puzzle which allowed me after much labor and ingenuity to come up with a different product, then restitution becomes much less plausible. The tort of misappropriation balances precisely on this equipoise between respect for (intellectual) labour and avoiding problems of foisting. ${ }^{44}$ This tort considers

\footnotetext{
${ }^{43}$ As, arguably, occurred in the very case that gave rise to the tort of misappropriation. International News Serv. V. Associated Press, 248 U.S. 215 (1918).

${ }^{44}$ Gordon, pp. 210-13.
} 
whether your release of information or ideas into the world signals a releasing of claims over them - or whether there are restitutionary strings attached. Duty Imposing Powers allow us to finesse distributive outcomes in a way that reflects the contributions of each person in cases where the market cannot plausibly do so ${ }^{45}$ - but such balancing requires myriad defeating conditions to yield correct answers.

Fifthly, one of the strongest reasons for allowing Appropriative Powers can in fact count against myriad other Duty Imposing Powers. We might think that an important moral requirement of a person is to have domains of regency and privacy (or at least the opportunity for such) where they can engage in any and all non-harming activities as they like - without others having authority over such actions. We may have direct ethical partiality for establishing such zones because, for instance, we hold that humans need to have parts of the world where their intentions alone are regent ${ }^{46}$ or where their selfexpressed personality is fully developed and reflected. ${ }^{47}$ Or we may have more derivative consequentialist reasons for favouring such arrangements. Insofar as such arguments are sound, they are pro tanto reasons for allowing private property. However, other Duty Imposing Powers can create duties which cut across such domains - respect for intellectual labor, public goods protection, privacy, or rights to the airwaves may require Duty Imposing Powers which determine that even a person acting in their own domain, on their own property, can have certain actions proscribed, or duty-imposing-strings attached to such actions.

Sixthly, one of the central functions of moral and legal injunctions is to guide behaviour. ${ }^{48}$ In order to provide such guidance it is important that individuals know what duties they are under, and can know and perhaps predict what activities others might undertake which are liable to impose new duties on them. Duties arising from both general rights and explicit consent fare well on this desideratum. General rights are usually easy to remember and apply, and they always inhere unless appropriately waived. Consensual duties are knowable because the individual has the conditions articulated before them, and explicitly agrees to their acceptance. But Duty Imposing Powers are much more complex - they are not always vested, we may not be sure when they are vested, and even when we are sure, the conditions and scope of the vested right may not be clear to the duty-recipient. Even though the Duty Imposing Power may be justified on all other grounds, it is nevertheless important that the duty-recipients can know what duties they are under and reliably predict what new duties they may come to be under.

Finally, we need to be aware of macro-level effects arising from the ongoing and systematic use of the Duty Imposing Power. Regarding the aforementioned tort of misappropriation, it can be difficult and expensive for courts to post hoc determine

\footnotetext{
${ }^{45}$ See Gordon’s (pp. 230-238) discussion of asymmetric market failure,.

46 The Kantian-inspired Will Theories of rights may understand rights as protected spheres of freedom. N. E. Simmonds, 'Rights at the Cutting Edge', in Matthew H. Kramer, N. E. Simmonds, and Hillel Steiner (eds) A Debate over Rights: Philosophical Enquiries, ed. (Oxford: Clarendon Press, 1998), pp. 112-232. at p. 126.

${ }^{47}$ G. Hegel, Hegel's Philosophy of Right, trans. T.M. Knox (Oxford: Clarendon Press, 1952), pp. 40-57. q.v. Dudley Knowles, Hegel and the Philosophy of Right, (London: Routledge, 2002), pp. 112-120.

${ }^{48}$ Guidance - its importance and its limitations - becomes apposite in analyzing that most invidious of duty-impositions - the retrospective creation of law. See C. J. G. Sampford et al., Retrospectivity and the Rule of Law (New York: Oxford UP, 2006).
} 
whether an activity was actionable, and if so what the appropriate restitution should be. ${ }^{49}$ The mechanism of prior consent, occurring through the market, may not give judicious answers in all such cases, but it avoids the prohibitive macro-level costs of continual appeal to the courts.

With these seven considerations in hand, we can consider their application to Appropriative Powers. What would an Appropriative Power look like if it were attenuated to avoid all these concerns? Supposing Appropriative Powers to be cabined by robust universalisability and the condition of non-worsening, the first five conditions do not seem to present serious additional problems - though more would have to be said about the fourth condition and the ways in which property rights might inadequately respect others' labor and their contributions to a project. The answer to this question is crucial to understanding private property's relation to both public goods (communal labor) and intellectual property (labor which inevitably cuts across property boundaries.) The sixth concern - concerning the guidance of behavior - may be significantly ameliorated by the physical marking of property, as a way of signalling that it no longer resides in the commons. Ultimately, the major concerns vis-à-vis Appropriative Powers are created by the final consideration. Macro-level effects combined with concerns for non-worsening create two concerns with Appropriative Powers which, arguably, introduce important types of worsening not observed in other rights. The first is large-scale ecological worsening; the second is that private property regimes (as currently operative, at least) allow one person to have comparatively more powerful political and legal representation than another.

Though Appropriative Powers avoid at least some of the above seven concerns, all seven are all germane to our assessment of such powers in the sense that these conditions allow us to distinguish between Appropriative Powers and putatively analogous Duty Imposing Powers advanced in the literature (such as the imposition of duties to perform at dinner-time, ${ }^{50}$ or those imposed by deliberately risking drowning in order to be rescued ${ }^{51}$ ).

Before concluding, and with the above seven considerations in hand, we can turn our attention to an intriguing question: can Duty Imposing Powers rightfully impose positive duties? That is, can Duty Imposing Powers create new ways in which you must act so as to benefit me (positive duties), or do they exclusively involve no more than articulating new restrictions on your activities (negative duties)? In answering this query, it is worth distinguishing two types of positive duties. One class of positive duties demands that I cede you some of my property. Another class enjoins me to undertake some specific action on your behalf. This last type of positive duty seems a rare result of Duty Imposing Powers; the reporting of crimes being the lone enforceable exemplar within my list of well-accepted Duty Imposing Powers. Perhaps this imposition may be defendable because of its crucial contribution to the institutions of justice, and because the duty may only be deliberately imposed on another person in exceptional situations. The other positive actions prescribed by Duty Imposing Powers are less onerous and typically only socially, not politically, sanctioned; these include expressing respect for

${ }^{49}$ Gordon, pp. 202, 219.

${ }^{50}$ Wenar, 'Original Acquisition', p. 807.

${ }^{51}$ Waldron, pp. 269-70. 
great moral actions and perhaps being willing to protect cultural artifacts. Contrariwise, the first type of positive duty is well evinced - actions of rescue, salvage and mistaken payment do impose new duties to cede property. Notably however, in all these cases the non-worsening condition is nevertheless met; the action which activated the duty is straightforwardly beneficial to the duty-acquirer, and the highly curtailed functioning of the Duty Imposing Power in each case requires that the duty-acquirer cannot suffer a net loss. The myriad other Duty Imposing Powers listed imposed only negative duties.

Several of the above considerations allow us to see why the unilateral imposition of positive duties should be so strongly curtailed. To impose positive duties on another can amount to a sizable intrusion into their lives, and clearly presses heavily against the non-worsening condition. p21 second paraThis will especially be so if one person is exposed to multiple and cumulative impositions of positive duties from a variety of sources. Even more worrisome, Duty Imposing Powers which impose positive actions might allow for personal and officious intrusion into others' lives. Further, the moral guidance exigency emphasizes firstly that persons need to be able to know and predict to what duties they will be exposed, and secondly need to be able to plan their lives with these factors in mind. If individuals can non-consensually impose positive duties on others (and ex fortiori are motivated to do so, because they are ex hypothesi advantaged by doing so) this latter desideratum in particular seems difficult to meet. These considerations explain why the imposition of positive duties only occurs under highly restricted conditions.

This conclusion does not reject positive duties per se or suggest that positive duties cannot be created by suddenly arising circumstances. Rather, the voluntary and deliberate imposition of positive duties, advantageous to the person imposing the duties, is particularly morally problematic. This result meshes with the common intuition that those circumstances where positive duties seem to most acceptably arise are cases where the subject gaining from those duties has not deliberately acted so as to impose them, for instance, duties of nurture to children, succour to the disaster-stricken or drowning, and support to those willing to work who through no fault of their own cannot find employment.

In sum, Duty Imposing Powers do invite specific moral problems which general claim rights and consensual duties do not. Any of the above seven criteria may potentially be brought to bear as an important moral reason not to accept a proposed Duty Imposing Power - as a way in which this Duty Imposing Power fails criteria which other rights pass. This analysis also suggests we must be careful in making swift analogies from one Duty Imposing Power (which does not breach these standards) to another (which does) and then in assessing the acceptability of the former by reference to the unacceptability of the latter. For instance, Robert Nozick analogises from Hart's principle of restrictive mutual obligations to cases of straightforward foisting. ${ }^{52}$ The foregoing analysis provides us with the resources necessary to assess the cogency of these types of casuistry.

Drawing together the conclusions of each section, we can see that Appropriative Powers cannot be pilloried simply because of their status as Duty Imposing Powers - for many crucial moral interests are served by Duty Imposing Powers. Without Duty

${ }^{52}$ Nozick, pp. 90-95. 
Imposing Powers, the moral law would struggle to respond appropriately to changes in the world, and may stringently impose ongoing and onerous duties which are wasted on the beneficiary. When criteria are put forward designed to curtail Appropriative Powers, this merely opens the question of the justification for those criteria. A natural way to voice concern with Appropriative Powers is to show how they fail independently motivated desiderata which other well-accepted rights (including general rights, Duty Activating Powers and other Duty Imposing Powers) do not fail. The foregoing analysis suggests that many provisos put forward in the property-rights literature in fact advance criteria which well-accepted rights would fail. In their place I have put forward a miscellany of desiderata - including specific construals of 'universalisability' and 'nonworsening' and avoidance of the seven concerns discussed in $\S 4$ - which distinguish potentially worrisome features of Appropriative Powers and Duty Imposing Powers which are not found in well-accepted rights. These desiderata allow us to demarcate the morally relevant distinctions between different types of rights, and hence to articulate what an Appropriative Power would look like when it is made to answer to the criteria we find at work in these more basic rights.

In closing, I would like to gesture toward a larger dialectic of which this argument may be considered one thread. I have not said enough to assure the sceptical reader that Appropriative Powers are of a piece with other more basic rights (e.g. general claim rights like bodily sanctity, Duty Activating Powers like freedom of association, and Duty Imposing Powers like possession, procreation and maturation). However, this argument has at least contributed to the cogency of this possibility, that is, to the dissolution of any bright-line difference between Appropriative Powers and other rights. Appropriative Powers have effects in and on the material world - but so do many well-accepted rights. Appropriative Powers involve the unilateral imposition of duties, but so do many wellaccepted rights. Appropriative Powers have widespread consequences for material, social, positive-freedom and final-utility inequalities, but so do many rights - and several at least as egregiously. The ultimate dissolution of this bright-line distinction, were it to be sustained, would be significant because it is lynchpin in the most popular politico-ethical theories of our time. Liberal-egalitarians require it in order to quarantine their egalitarian designs from infecting more basic rights. They need to assert that Appropriative Powers alone, as distinct from all other rights, have significant consequences for morally invidious inequality. Libertarians require the distinction just as much, but in precisely the reverse manner, in order to exempt property rights from being subject to the same considerations which demarcate and qualify basic rights. Libertarians want to believe that Appropriative Powers alone, as distinct from all other rights, cannot be a way of interfering with or worsening others' lives. Each paradigm relies pivotally on Appropriative Powers being approached and assessed as if they were sui generis. I have not provided the type of positive arguments which would compel the strong conclusion that Appropriative Powers are part and parcel of our normal package of human rights. However, by demystifying one important feature of Appropriative Powers - their status as Duty Imposing Powers - I hope to have at least taken a small step in opening the possibility of this conclusion. ${ }^{53}$

\footnotetext{
${ }^{53}$ This paper has benefited from critique by Julian Lamont and an anonymous referee from the Philosophical Quarterly.
} 